\title{
SISTEM PAKAR DIAGNOSA HAMA DAN PENYAKIT PADI DENGAN METODE BAYESIAN BERBASIS CERTAINTY FACTOR
}

\author{
Dwi Puji Raharjo ${ }^{1}$, Andharini Dwi Cahyani², Bain Khusnul Khotimah ${ }^{3}$ \\ ${ }^{1,2,3}$ Program Studi Teknik Informatika, Universitas Trunojoyo Madura \\ Jl. Raya Telang PO BOX 2 Kamal Bangkalan-69162 \\ E-mail: 1 dwi.puji.raharjo.26.03@ gmail.com
}

\begin{abstract}
ABSTRAK
Banyak petani yang mendapatkan hasil panen kurang maksimal. Hal itu disebabkan oleh hama maupun penyakit tanaman padi. Hama dan penyakit memiliki jenis dan gejala yang berbeda. Untuk jenis hama dan penyakit diantaranya: penggerek batang, hawar daun bakteri, dan lainlain. sedangkan gejala dari hama maupun penyakit tanaman padi antara lain: adanya ngengat kupu-kupu, anakan berkurang, daun padi berwarna kuning, dan lain-lain. Untuk mempermudah mendiagnosa jenis hama dan penyakit tanaman padi, dibutuhkan adanya sistem pakar yang cara kerjanya hampir sama dengan seorang pakar dalam bidangnya. Gejala-gejala yang terdapat pada sistem sering mengandung ketidakpastian karena fakta yang didapat di lapangan tidak sesuai dengan panduan seorang pakar. Untuk mengatasi masalah ketidakpastian tersebut, sistem pakar mengadopsi metode Certainty Factor untuk menganalisa berdasarkan gejala-gajala yang terdapat pada masalah yang terjadi. Dengan metode Certainty Factor pada sistem akan didapatkan tingkat kepastian terhadap suatu fakta yang akan menghasilkan sebuah diagnosa. Hasil dari sistem akan mampu melakukan diagnosa berdasarkan gejala-gejala yang ada meskipun terdapat gejala-gejala yang mengandung ketidakpastian. Untuk mengukur derajat kemunculan suatu hama ataupun penyakit berdasarkan gejala-gejala digunakanlah Probabilitas Bayesian.
\end{abstract}

Kata kunci: Sistem Pakar, Hama dan Penyakit Tanaman Padi, Probabilitas Bayesian, Certainty Factor.

\begin{abstract}
There are many farmers who get harvests less than what they expected. It's all because of pest and the unhealthy rice. Pest and a disease of rice has different kind of indications. They are borer, blight of leaf, bacteria, and many more. And for the indications of pest and a disease of rice are; the existence of butterfly, the decreasing tillers, the leaf that becomes yellow, and many more. To make it easer to detect the pest and the diseases of rice, we need a kind of expert system that can act like the real expert. The indications of pest and diseases of rice can not be detected accurately at times because the real fact doesn't really match with what the expert diagnoses. And to make a deal with that problem, the expert system adopts the method of Certainly Factor to diagnose the indications of the problem that occurs. By adopting the method of Certianly Factor it will be able to detect the accuracy of diagnosis. The expert system will be able to conclude the indications even they contain non accurate facts. To calculate the accuracy of the diagnosis made by the expert system, we can use the method of Bayesian Probability.
\end{abstract}

Keyword: Expert System, Pests and Diseases of Rice, Bayesian Probability, Certainly Factor. 


\section{PENDAHULUAN}

Padi merupakan tanaman pangan yang menghasilkan beras sebagai makanan pokok sebagian besar rakyat Indonesia. Karena itu, hampir di seluruh wilayah Indonesia terdapat tanaman padi. Salah satunya di kabupaten Lamongan provinsi Jawa Timur, tepatnya di kecamatan Laren. Rata-rata masyarakat di daerah tersebut berprofesi sebagai petani padi. Namun dalam perjalanannya, tidak sedikit petani padi yang mendapatkan masalah sehingga mengakibatkan hasil panen kurang maksimal. Permasalahan yang sering didapatkan oleh para petani adalah serangan hama dan penyakit pada saat padi ditanam.

Akan tetapi tidak mudah bagi para petani untuk mendiagnosa jenis hama maupun penyakit yang menyerang tanaman padi. Selama ini, para petani yang ingin mengetahui masalaha tersebut harus berkonsultasi dengan berkunjung ke kantor UPT Dinas Pertanian dan Kehutanan kecamatan Laren kabupaten Lamongan atau memanggil pegawai dinas pertanian untuk datang dan mengamati jenis hama maupun penyakit yang terdapat pada tanaman padi di sawah mereka.

Dewasa ini perkembangan teknologi dalam bidang kecerdasan buatan (artificial inteligence) sangatlah pesat. Dengan salah satu terapannnya adalah sistem pakar (expert system). Maka dari itu, solusi yang tepat untuk menangani permasalahan seperti di atas yakni dengan membuat suatu sistem pakar yang dimana sistem tersebut dapat menyelesaikan permasalahan dengan meniru cara yang dilakukan oleh seorang pakar atau ahli dalam mengatasi permasalahan pada bidangnya.

Sistem pakar yang ditanamkan mengadopsi metode Certainty Factor untuk menganalisa terdapatnya gejalagejala yang mengandung ketidakpasian karena fakta yang didapatkan tidak sesuai dengan aturan dari pakar. Pada sistem tersebut hasil diagnosa akan menampilkan nilai Certainty Factor yang menunjukan tingkat kebenaran hasil diagnosa. Dimana nilai Certainty Factor terbaik berdasarkan nilai Certainty Factor tertinggi untuk menghasilkan tingkat kepercayaan semakin optimal [2]. Pada sistem tersebut juga digunakan Probabilitas Bayesian untuk mengukur bobot kemunculan suatu hama ataupun penyakit berdasarkan gejala-gejala. Tujuan dari penelitian ini untuk mempermudah para petani padi dalam menangani hama dan penyakit padi layaknya seorang pakar.

\section{METODE}

a)

Faktor Ketidakpastian
(Uncertainty Factor)
Dalam menghadapi suatu
masalah sering ditemukan jawaban yang tidak memiliki kepastian penuh. Ketidakpastian ini bisa berupa probabilitas atau keboleh jadian yang tergantung dari hasil suatu kejadian. Hasil yang tidak pasti disebabkan oleh dua faktor yaitu aturan yang tidak pasti dan jawaban pengguna yang tidak pasti atas suatu pertanyaan yang diajukan oleh sistem. Hal ini sangat mudah dilihat pada sistem diagnosis, dimana pakar tidak dapat mendefinisikan tentang hubungan antara gejala dengan penyebabnya secara pasti, dan pasien tidak dapat merasakan suatu gejala dengan pasti pula. Pada akhirnya ditemukan banyak kemungkinan diagnosis [12].

Sistem pakar harus mampu bekerja dalam ketidakpastian. Sejumlah teori telah ditemukan untuk menyelesaikan ketidakpastian, termasuk diantaranya probabilitas klasik (classical probability), probabilitas Bayes (Bayesian probability), teori Hartley berdasarkan himpunan klasik (Hartley theory based on classical sets), teori Shannon berdasarkan pada probabilitas (Shannon theory based on probability), teori Dempster-Shafer (Dempster Shafer theory), teori fuzzy Zadeh (Zadehís fuzzy theory) dan faktor kepastian (Certainty 
Factor) [12]. Dalam penelitian ini yang digunakan adalah gabungan antara Probabilitas Bayesian dan faktor kepastian.

\section{b) Faktor Kepastian (Certainty Factor) \\ Certainty Theory ini diusulkan} oleh Shortliffe dan Buchanan pada tahun 1975 untuk mengakomodasi ketidakpastian pemikiran (inexact reasoning) seorang pakar. Teori ini berkembang bersamaan dengan pembuatan sistem pakar MYCIN. Team pengembang MYCIN mencatat bahwa tim ahli sering kali menganalisa informasi yang ada dengan ungkapan seperti misalnya: mungkin, kemungkinan besar, hampir pasti. Untuk mengakomodasi hal ini tim MYCIN menggunakan certainty factor $(\mathrm{CF})$ guna menggambarkan tingkat keyakinan pakar terhadap masalah yang sedang dihadapi.. Certainty Factor didefinisakn sebagai berikut :

$$
\begin{aligned}
& \mathrm{CF}(\mathrm{H}, \mathrm{E})=\mathrm{MB}(\mathrm{H}, \mathrm{E})-\mathrm{MD}(\mathrm{H}, \mathrm{E}) \ldots . .(1) \\
& \text { Dimana: } \\
& \mathrm{CF}(\mathrm{H}, \mathrm{E}) \text { : Certainty factor dari } \\
& \text { hipotesis } \mathrm{H} \text { yang } \\
& \text { dipengaruhi oleh gejala } \\
& \text { (evidence) E. Besarnya } \mathrm{CF} \\
& \text { berkisar antara -1 sampai } 1 \text {. } \\
& \text { Nilai -1 menunjukkan } \\
& \text { ketidakpercayaan mutlak, } \\
& \text { sedangkan nilai } 1 \\
& \text { menunjukkan kepercayaan } \\
& \text { mutlak. }
\end{aligned}
$$

$\mathrm{MD}(\mathrm{H}, \mathrm{E})$ : Ukuran ketidakpercayaan (Measure Of Disbelief) terhadap hipotesis $\mathrm{H}$ yang dipengaruhi gejala $\mathrm{E}$.

Probabiltas Bayesian adalah salah satu cara untuk mengatasi ketidakpastian dengan menggunakan Formula Bayes yang dinyatakan sebagai berikut [12] :

$$
\mathrm{P}(\mathrm{H} \mid \mathrm{E})=\frac{\mathrm{P}(\mathrm{E} \mid \mathrm{H}) \mathrm{P}(\mathrm{H})}{\mathrm{P}(\mathrm{E})}
$$

Dimana :
$\mathrm{P}(\mathrm{H} \mid \mathrm{E})$ : Probabilitas hipotesa $\mathrm{H}$ jika terdapat evidence $\mathrm{E}$

$\mathrm{P}(\mathrm{E} \mid \mathrm{H})$ : Probabilitas munculnya evidence E jika diketahui hipotesa $\mathrm{H}$

$\mathrm{P}(\mathrm{H})$ : Probabilitas hipotesa $\mathrm{H}$ tanpa memandang evidence apapun

$\mathrm{P}(\mathrm{E})$ : Probabilitas evidence $\mathrm{E}$

Sampai saat ini ada dua model yang sering digunakan untuk menghitung tingkat keyakinan $(\mathrm{CF})$ dari sebuah rule adalah sebagai berikut:

a. Menggunakan Metode 'Net Belief' Tingkat keyakinan (CF) dalam metode net belief dapat dihitung dengan rumus sebagai berikut :

$\mathrm{CF}($ Rule $)=\mathrm{MB}(\mathrm{H}, \mathrm{E})-\mathrm{MD}(\mathrm{H}, \mathrm{E}) \ldots \ldots .1)$

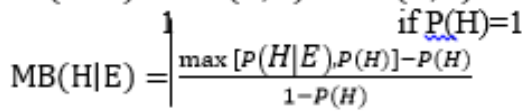

$$
\begin{aligned}
& \left.\mathrm{MD}(\mathrm{H} \mid \mathrm{E})\right|^{1} \quad \text { if } \mathrm{P}(\mathrm{H})=0 \\
& \underline{\min [P(H \mid E), H(H)]-P(H)} \\
& \mathrm{P}(\mathrm{H}) \quad \text { dan } \quad \mathrm{P}(\mathrm{H} \mid \mathrm{E})
\end{aligned}
$$

mempresentasikan keyakinan dan ketidakyakinan pakar. Untuk menghitung nilai $\mathrm{P}(\mathrm{H} \mid \mathrm{E})$ nantinya akan menggunakan Probabilitas Bayesian.

Jika ada kaidah lain termasuk dalam hipotesis yang sama tetapi berbeda dalam factor kepastian, maka perhitungan factor kepastian dari kaidah yang sama dihitung dari penggabungan fungsi untuk factor kepastian yang didefinisakn sebagai berikut :

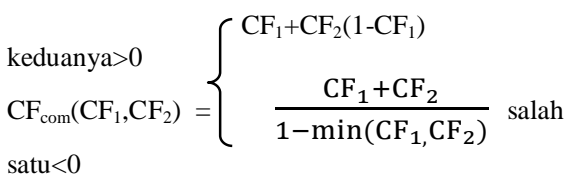

keduanya $<0$...(5)

Dimana $\mathrm{CF}_{\text {Combine }}$ digunakan bergantung pada apakah factor kepastian positif atau negative [2].

b. Dengan menggali dari hasil wawancara dengan pakar [13]. Nilai $\mathrm{CF}$ (Rule) didapat dari interpretasi term dari pakar menjadi nilai $\mathrm{CF}$ tertentu (lihat tabel 2.1) 
Tabel 1. Nilai CF (Rule) dari Pakar

\begin{tabular}{|l|c|}
\hline $\begin{array}{l}\text { Uncertain Term } \\
\text { (Ketidakpastian) }\end{array}$ & CF \\
\hline $\begin{array}{l}\text { Definitely not (Pasti tidak) } \\
\text { Almost certainty not (Hampir pasti }\end{array}$ & -1.0 \\
tidak) & -0.8 \\
Probably not (Mungkin tidak) & -0.6 \\
Maybe not (Barang kali tidak) & -0.4 \\
Unkown (Tidak tahu) & $-0.2 \mathrm{~s} / \mathrm{d} 0.2$ \\
Maybe (Barang kali) & 0.4 \\
Probably (Mungkin) & 0.6 \\
Almost certainty (Hampir pasti) & 0.8 \\
Definitely (Pasti) & 1.0 \\
\hline
\end{tabular}

c) RANCANGAN SISTEM

Flowchart Meode Certainty

Factor merupakan gambaran dari alur metode Certainty Factor yang dikerjakan secara keseluruhan maupun secara terpisah dalam suatu proses tertentu dan menjelaskan prosedur - prosedur yang ada.

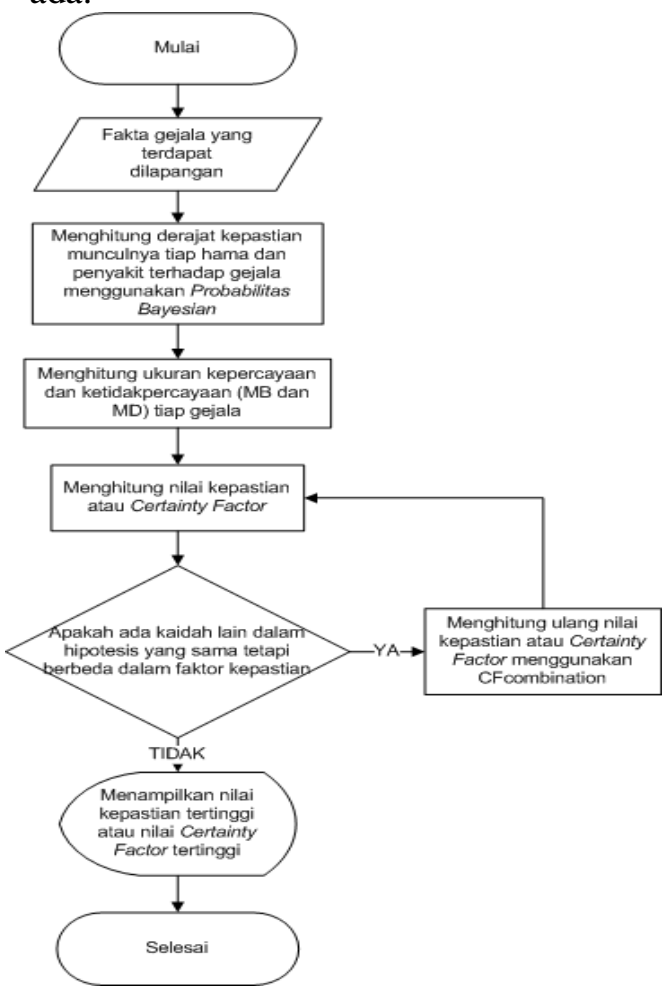

Gambar 1. Flowchart Metode Certainty Factor

Berikut keterangan tiap proses dari gambar 1:

1. Menentukan data master atau fakta yang terdapat dilapangan.

2. Data master yang telah ditentukan kemudian dihitung bobot kepastian munculnya tiap hama dan penyakit terhadap gejala menggunakan probabilitas Bayesian.

Menggunakan rumus persamaan (2).

3. Menghitug ukuran kepercayaan dan ketidakpercayaan (Measure Of Belief dan Measure Of Disbelief) menggunakan rumus persamaan (3) dan (4).

4. Setelah dilakukan penghitungan ukuran kepercayaan dan ketidakpercayaan, selanjutanya akan dihitung nilai kepastian atau Certainty Factor-nya.

5. Jika ada kaidah lain dalam hipotesis yang sama tetapi berbeda dalam faktor kepastian, maka nilai Certainty Factor atau nilai kepastiannya akan dihitung ulang dengan CFcombination, rumus persamaan (5).

6. Jika tidak ada lagi kaidah lain pada hipotesis yang sama maka nilai kepastian atau Certainty Factor akan ditampilkan.

Flowchart Sistem merupakan gambaran dari alur sistem yang dikerjakan secara keseluruhan maupun secara terpisah dalam suatu proses tertentu dan menjelaskan prosedur prosedur yang ada dalam sistem

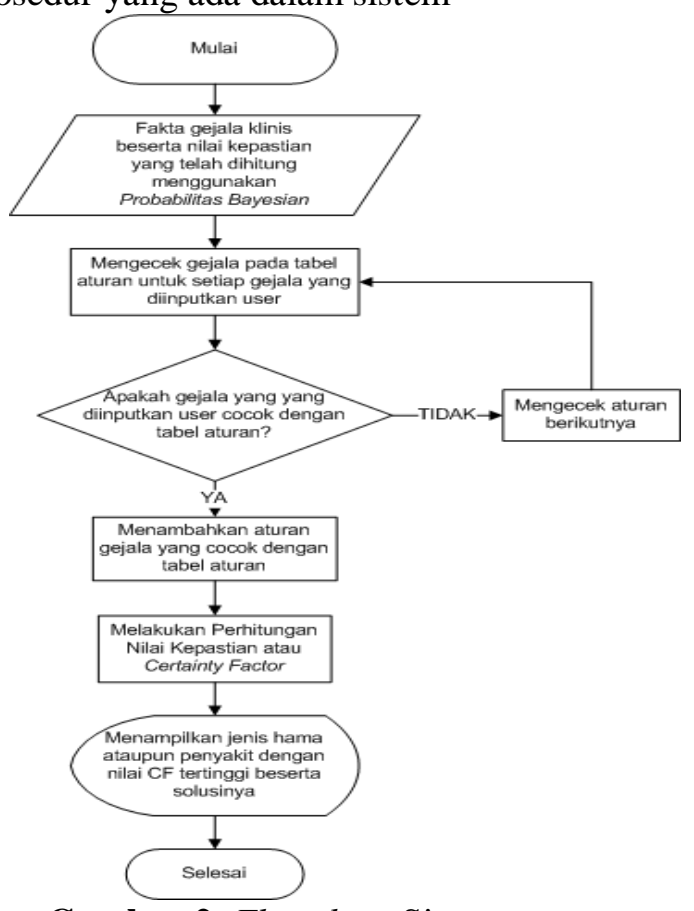

Gambar 2. Flowchart Sistem 
dari gambar 2:

Berikut keterangan tiap proses

1. Sistem menampilkan fakta gejala klinis yang diambil dari buku masalah lapang yang dicetak oleh KOPKARLITAN Balai Besar Penelitian Tanaman Padi Cetakan keempat Tahun 2008 yang digunakan sebagai panduan oleh UPT Dinas Pertanian dan Kehutanan kecamatan Laren kabupaten Lamongan. Kemudian tiap gejala dihitung nilia kepastian atau derajat kemunculannya menggunakan data verifikasi hasil konsultasi jenis hama dan penyakit padi oleh petani kepada pegawai penyuluhan lapang UPT Dinas Pertanian dan Kehutanan Kecamatan Laren Kabupaten Lamongan tahun 2014.

2. Setelah user men-ceklist atau telah menginputkan data gejala, gejala akan dicocokkan dengan aturan yang ada pada database sistem.

3. Jika cocok, sistem akan menyimpan aturan tersebut dan jika tidak sistem akan mencocokkan ulang dengan aturan baru.

4. Setelah gejala tersebut disimpan karena cocok dengan aturan, maka kemudian sistem akan menghitung nilai kepastiannya atau Certainty Factor.

5. Sistem akan menampilkan hasil perhitungan nilai Certainty Factor dimana nilai $\mathrm{CF}$ tertinggi merupakan hasil dari diagnose akhir. Sistem juga akan menampilkan solusi untuk menangani hasil diagnose tersebut.

Dalam sistem pakar diagnosa hama dan penyakit padi ini terdapat tiga pengguna yakni: user public, user member, dan admin.

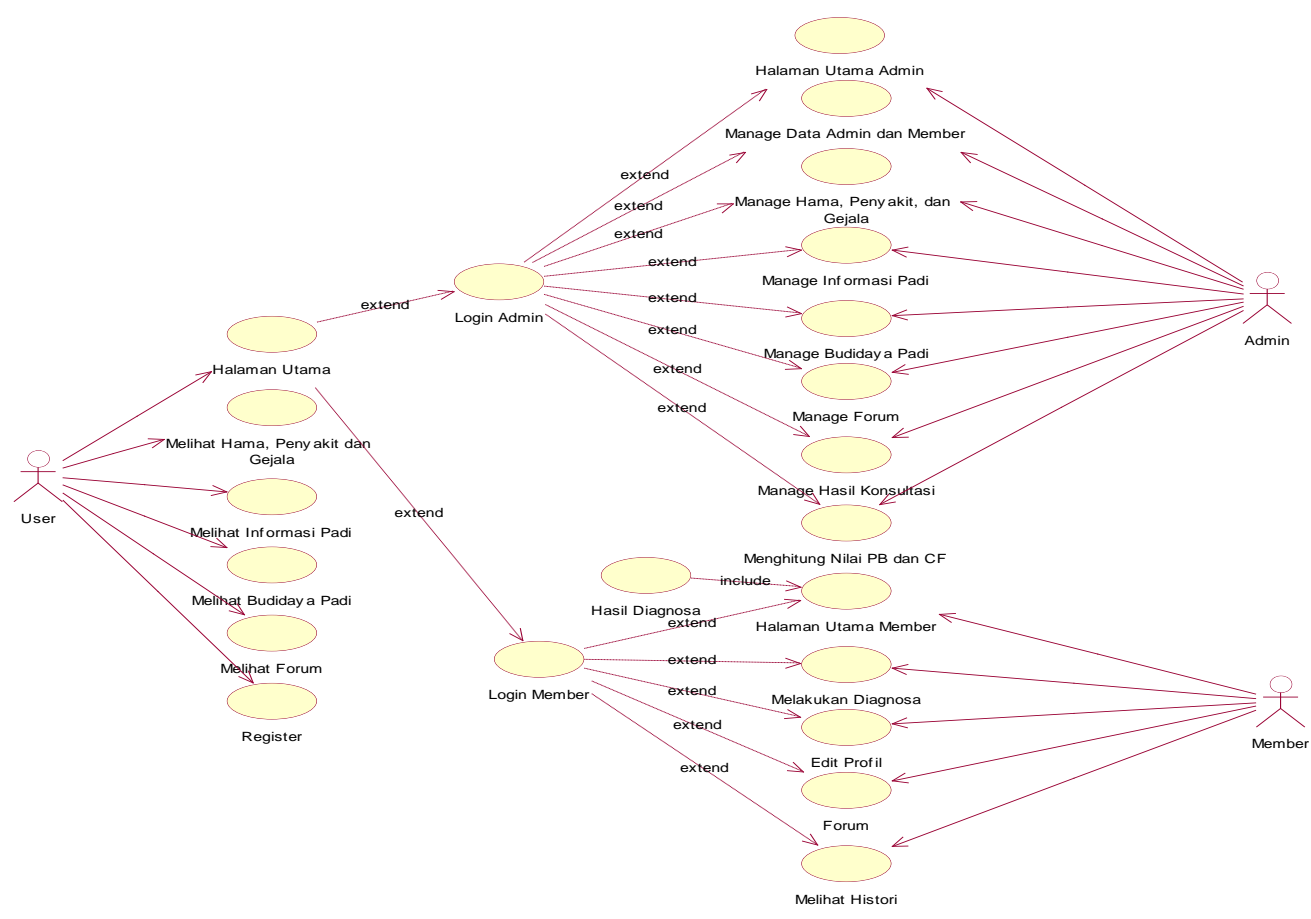

Gambar 3. Use Case Diagram

Dapat dilihat pada gambar $3.2 \mathrm{di}$ atas bahwa pada sistem pakar diagnosa hama dan penyakit padi ini terdapat tiga user, yakni: user public/user, admin, dan user member/member. User public hanya dapa melihat informasi-informasi seperti informasi hama penyakit gejala, informasi padi, informasi budidaya padi dan hanya dapat melihat forum tanpa bisa berkomentar. Namun setelah login baik menjadi member maupun admin, hak aksesnya telah berubah. Jika login sebagai member pengguna sudah dapat melihat halaman utama member 
membuat forum ataupun berkomentar pada forum, dapat melakukan diagnosa dan melihat hasil serta riwayat diagnosa yang telah dilakukan. Pengguna juga bisa merubah profilnya Dan jika pengguna login sebagai admin, maka pengguna dapat mengunjungi halaman utama admin. Kemudian pengguna memiliki hak akses untuk mengelola data pada sistem seperti: mengelola data admin dan member, mengelola data hama penyakit dan gejala, mengelola informasi padi, mengelola budidaya padi, mengelola forum, mengelola hasil konsultasi, dan menghitung nilai $\mathrm{PB}$ dan $\mathrm{CF}$. admin juga dapat menngubah profilnya.

\section{HASIL DAN PEMBAHASAN}

a. Basis Pengetahuan

Penelitian ini menggunakan data training konsultasi hama dan penyakit padi yang diperoleh dari hasil konsultasi petani ke UPT Dinas Pertanian dan Kehutanan Kec. Laren Kab. Lamongan selama tahun 2014. Data training terdiri dari total data konsultasi petani sebanyak 145. Sedangkan data testing diperoleh dari hasil konsultisai petani di awal tahun 2015 sebanyak 18 data. Untuk jenis hama dan penyakit beserta gejala didapatkan dari buku masalah lapang yang dicetak oleh KOPKARLITAN Balai Besar Penelitian Tanaman Padi Cetakan keempat Tahun 2008 yang digunakan sebagai panduan oleh UPT Dinas Pertanian dan Kehutanan kecamatan Laren kabupaten Lamongan. dengan jumlah data hama sebanyak 17 data, data penyakit sebanyak 13 data, dan gejala sebanyak 92 data.

b. Pengujian Sistem

Untuk proses pengujian kita menentukan tabel-tabel yang akan tersimpan dalam database. Setelah diketahui, maka langkah selanjutnya yaitu membuat interface agar memudahkan untuk mengelolah data kedalam database, serta membuat interface untuk melakukan konsultasi diagnosa hama dan penyakit padi.

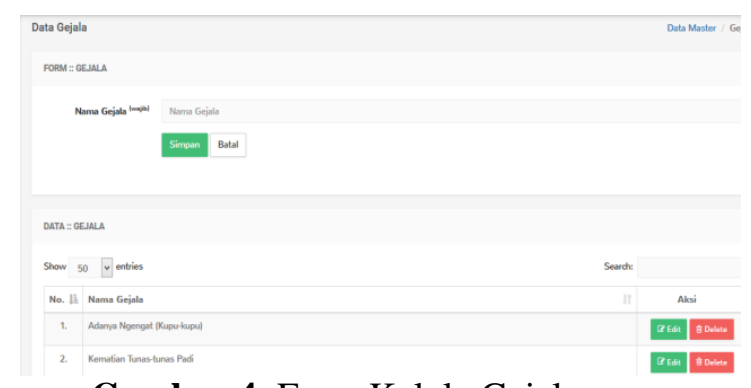

Gambar 4. Form Kelola Gejala

Pada gambar 4 merupakan Form Kelola Gejala digunakan untuk melakukan penambahan, pengubahan, dan penghapusan jenis-jenis gejala yang ada.

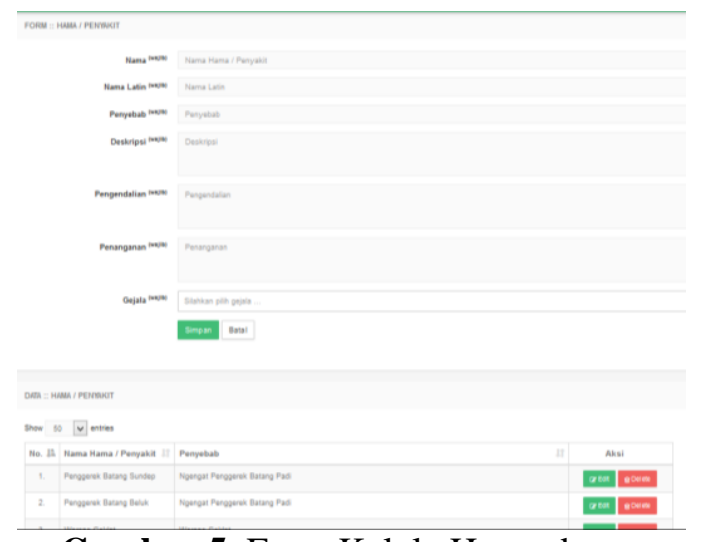

Gambar 5. Form Kelola Hama dan Penyakit

Pada gambar 5 merupakan Form Kelola Hama dan Penyakit digunakan untuk melakukan penambahan, pengubahan, dan penghapusan jenis-jenis Hama dan Penyakit Padi.

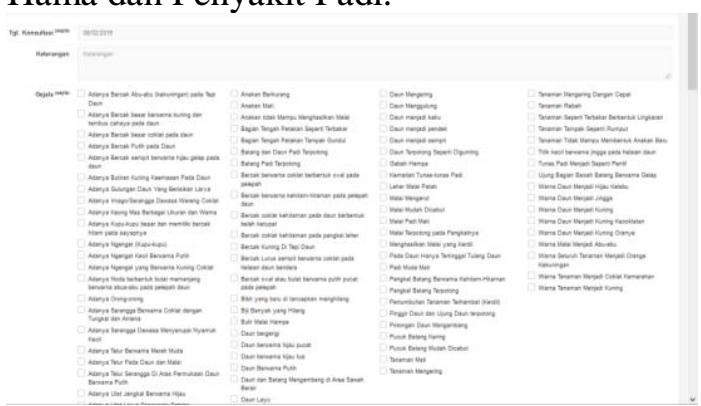

Gambar 6. Form Kelola Konsultasi

Pada gambar 6 merupakan Form Kelola konsultasi digunakan untuk melakukan penambahan, pengubahan, dan penghapusan jenis-jenis Hama dan Penyakit Padi. 


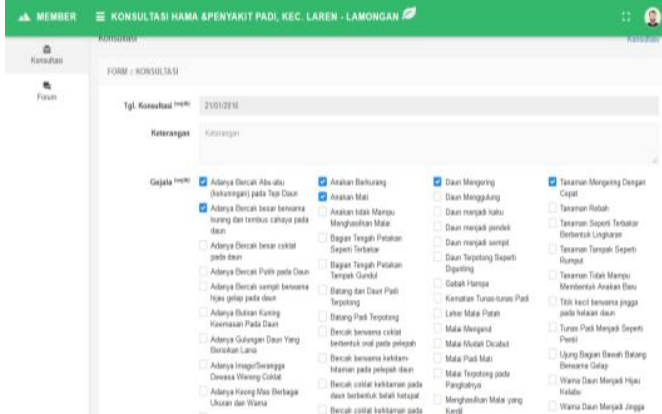

Gambar 7. Form Konsultasi

Pada gambar 7 merupakan form konsultasi yang berfungsi untuk melakukan konsultasi. Form ini interfacenya dibuat hampir sama dengan form kelola konsultasi. Namun untuk hak akses dibuat berbeda. Untuk form konsultasi hanya bisa diakses oleh user member, sedangkan form kelola konsultasi hanya bisa diakses oleh admin.

\section{c. Uji Akurasi Sistem}

Untuk menghitung tingkat akurasi sistem, dilakukan menggunakan 5 skenario dengan membandingkan hasil diagnosa sistem dan diagnosa dinas. Pada skenario pertama, data tahun 2014 hanya diambil 29 data untuk digunakan sebagai data training. Sedangkan data testing diambil keselurahan yakni sebanyak 18 data. Dengan skenario tersebut dihasilkan tingkat keakurasian sebesar 50\% dengan kecocokan 9 data konsultasi dan ketidak cocokan 9 data konsutasi. Untuk skenario kedua menggunakan data training sebanyak 58 dan data testing sebanyak 18 dan dihasilkan tingkat akurasi sebesar $72.22 \%$ dengan kecocokan 13 data dan ketidakcocokan 5 data. Untuk skenario ketiga diambil 87 data training dan 18 data testing serta menghasilkan tingkat akurasi sebesar $88.89 \%$ dengan kecocokan 16 data dan ketidakcocokan 2 data. Skenario keempat menggunakan 116 data training dan 18 data testing yabg menghasilkan tingkat akurasi sebesar $77.78 \%$ dengan kecocokan data 14 dan ketidakcocokan 2. Untuk skenario terakhir menggunakan data training sebanyak 145 dan data testing sebanyak 18 yang menghasilkan tingkat akurasi sebesar $88.89 \%$ dengan kecocokan data 16 dan ketidakcocokan 2 data. Dari kelima skenario tersebut didapatkan ratarata keakurasian sebesar $75.56 \%$.

Tabel 2. Uji Akurasi Sistem

\begin{tabular}{|c|c|c|c|c|c|}
\hline $\begin{array}{c}\text { N } \\
\text { o }\end{array}$ & $\begin{array}{c}\text { Data } \\
\text { Traini } \\
\text { ng }\end{array}$ & $\begin{array}{c}\text { Data } \\
\text { Testi } \\
\text { ng }\end{array}$ & $\begin{array}{c}\text { Coc } \\
\text { ok }\end{array}$ & $\begin{array}{c}\text { Tida } \\
\text { Coc } \\
\text { ok }\end{array}$ & $\begin{array}{c}\text { Akura } \\
\text { si (\%) }\end{array}$ \\
\hline 1 & 29 & 18 & 9 & 9 & 50.00 \\
\hline 2 & 58 & 18 & 13 & 5 & 72.22 \\
\hline 3 & 87 & 18 & 16 & 2 & 88.89 \\
\hline 4 & 116 & 18 & 14 & 4 & 77.78 \\
\hline 5 & 145 & 18 & 16 & 2 & 88.89 \\
\hline & \multicolumn{5}{|c|}{ Rata-rata } \\
\hline
\end{tabular}

Kelima skenario tersebut menjelaskan bahwa semakin sering suatu gejala muncul pada beberapa hama, penyakit dan waktu, maka nilai Probabilitasnya akan semakin kecil. Sedangkan jika suatu gejala hanya muncul pada satu hama maupun penyakit maka nilai Probabilitasnya adalah 1 atau pasti. Nilai Probabilitas sangat mempengaruhi nilai Certainty Factor. Semakin besar nilai Probabilitas, semakin besar pula nilai CF-nya.

\section{SIMPULAN}

Dari penelitian ini didapatkan beberapa kesimpulan, diantaranya:

1. Penggunaan Probabilitas Bayesian untuk menghitung bobot kemunculan suatu hama ataupun penyakit berdasarkan gejala pada sistem ini dapat diketahui bahwa bila suatu gejala hanya muncul pada sedikit hama ataupun penyakit, maka bobot kemunculannya akan semakin besar.

2. Bobot kemunculan suatu hama, penyakit maupun gejala yang telah dihitung menggunakan Probabilitas Bayesian sangat berpengaruh terhadap nilai Certainty Factor yang didapat. Semakin tinggi bobot kemunculan yang didapat maka akan semakin tinggi pula nilai $\mathrm{CF}$ untuk hama dan penyakit berdasarkan gejalanya.

3. Penggunaan Probabilitas Bayesian dan metode Certainty Factor pada sistem ini memiliki tingkat keakurasian diagnosa terhadap jenis hama dan penyakit rata-rata $75.56 \%$ 
berdasarkan jumlah data training yang digunakan.

4. Dengan menggunakan sistem ini, proses melakukan diagnosa terhadap gejala-gejala yang mengandung ketidakpastian dapat dengan cepat ditangani. Sehinggan diagnosa terhadap serangan Hama dan Penyakit tanaman padi dapat diperoleh dengan akurat.

\section{SARAN}

Untuk penelitian dan pengembangan lebih lanjut serta penyempurnaan sistem ini disarankan pembuatan sistem selanjutnya memperhatikan beberapa hal seperti :

1. Disarankan untuk menggunakan metode lain sehingga dapat dibandingkan keakuratannya.

2. Sistem ini dapat dikembangkan lebih lanjut untuk diagnosa penyakit tanaman jagung, kedelai, cabe, dan lain sebagainya.

3. Diharapkan penelitian selanjutnya memperhatikan bobot kemunculan gejala dan jenis penyakit agar memiliki tingkat keakurasian yang lebih maksimal.

\section{DAFTAR PUSTAKA}

[1] Syam Mahyuddin, Suparyono, Hermanto, S Wuryandari Diah. 2008. Masalah Lapang Hama, Penyakit dan Hara Tanaman Padi. KOPKARLITAN Balai Besar Penelitian Tanaman Padi.

[2] Khotimah, Bain Khusnul. 2010. Sistem Pakar Troubleshooting Komputer dengan metode Certainty Factor Menggunakan Probabilitas Bayesian (Strudi Kasus Laboratorium Jaringan Komputer). Rekayasa, Volume 3, Nomor 1, April 2010.

[3] Muhardi, Dedi. 2014. Sistem Pakar Menentukan Tingkat Depresi Mahasiswa Semester Akhir Menggunakan Metode Certainty Factor. Pelita Informatika Budi Darma, Volume: IV, Nomor 3, April 2014.
[4] Daniel, Gloria Virginia. 2010. Implementasi Sistem Pakar Untuk Mendiagnosis Penyakit Dengan Gejala Demam Menggunakan Metode Certainty Factor. 26Jurnal Informatika, Volume 6 Nomor 1, April 2010.

[5] Rohajawati Siti, Supriyati Rina. 2010. Sistem Pakar: Diagnosis Penyakit Unggas Dengan Metode Certainty Factor. ComIT, Vol 4 No. 1 Mei 2010, hlm 41 - 46.

[6] Daeli, Feresi. 2013. Sistem Pakar Menentukan IQ Anak yang Mengalami Reterdasi Mental Dengan Metode Certainty Factor (Studi Kasus: Pendidikan SLB/B Karya Murni). Pelita Informatika Budi Darma, Volume IV, Nomor 3, Agustus 2013.

[7] Anjas Sari, Nur. 2013. Sistem Pakar Mendiagnosa Penyakit Demam Berdarah Menggunakan Metode Certainty Factor. Pelita Informatika Budi Darma, Volume IV, Nomor 3, Agustus 2013.

[8] Latumakulita, Luther. 2012. Sistem Pakar Pendiagnosa Penyakit Anak Menggunakan Certainty Factor (CF). 122 Jurnal Ilmiah Sains Vol. 12 No. 2, Oktober 2012.

[9] Yastita, Sri,. Dewi Lulu, Yohana,. Perdana Sari, Rika. 2012. Sistem Pakar Penyakit Kulit Pada Manusia Menggunakan Metode Certainty Factor Berbasis Web. Seminar Nasional Teknologi Informasi, Komunikasi dan Industri (STNTIKI) 4 Pekanbaru, 3 Oktober 2012.

[10] Mahardika, Gede. 2012. Pengembangan Sistem Pakar Diagnosa Hama dan Penyakit Tanaman Padi Menggunakan Metode Certainty Factor Berbantuan Metode Kuantifikasi Pertanyaan (Studi Kasus: Laboratorium Pengamatan Hama dan Penyakit, di Desa Tangguwisia, Kecamatan Seririt). Kumpulan Artikel Mahasiswa Pendidikan Teknik Informatika 
(KARMAPATI) Volume 1, Nomor 1, Mei 2012.

[11] Orisa, Mira,. Budi Santosos, Purnomo,. Setyawati, Onny. 2010. Sistem Pakar Diagnosis Penyakit Kambing Berbasis Web Menggunakan Metode Certainty Factor. Jurnal EECCIS Vol 8, No. 2, Desember 2010.

[12] Yudi,. Laila. Aplikasi Sistem Pakar untuk Diagnosa Hama Jeruk dan Pengobatannya Menggunakan Metode Certainty Factor.

[13] Kusrini. Penggunaan Certainty Factor dalam Sistem Pakar untuk Melakukan Diagnosis dan Memberikan Terapi Penyakit Epilepsi dan Keluarganya. 